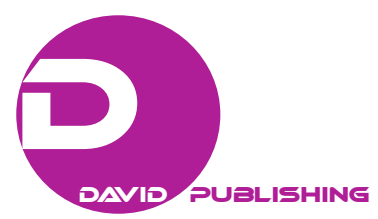

\title{
An Evaluation of a Chinese Language Textbook: From Students’ Perspective*
}

\author{
Yu Dongxing \\ East China Normal University, Shanghai, China
}

\begin{abstract}
Textbooks provide teachers with guidance in course and activity design. It assures a measure of structure, consistency, and logical progression in a class. The present paper is part of a broader study on the evaluation of textbooks used in teaching Chinese as a foreign language which were broadly used in Denmark. The need for such study was required by the increased interest shown by foreign students in learning Chinese at different high schools and universities in Denmark. The key assumption of my research is that this type of assessment can provide useful information in Chinese teaching and help both teachers and students to choose and use teaching materials more efficiently. The purpose of this research project was to determine the overall pedagogical value and suitability of the book towards students' needs. This paper outlines a procedure for language textbook analysis from the perspective of students' evaluation. The evaluation form, which includes five sections, could also be of use to those involved in language materials publishing, and government officials involved in the approval of language materials. The results of the research show the assessment of Intergrated Chinese is not good enough as expectation or estimation in normal. Although the textbook had met students' basic needs and it could be a good book in the hand of a good teacher. Chinese language textbook could focus more on meeting the students' need in real life communication and developing students’ own critical thinking.
\end{abstract}

Keywords: textbook evaluation, students’ perspective, critical thinking

\section{Introduction}

A textbook occupies a very important place in Chinese language education. And the analysis and evaluation of existing textbooks plays a very important role in the process of developing new textbooks. Analyzing and fixing problems with existing textbooks provides the basis, on which the direction of development of new teaching materials can be presented.

A quality textbook should be a model of good teaching and should facilitate students' language learning. However, language practitioners often choose a textbook based on cursory impressionistic evaluations and practical factors unrelated to pedagogy. Even if practitioners use one of the numerous checklists and questionnaires developed since the 1970's to make their predictive evaluation more systematic, the selected materials may still not provide optimal conditions for language learning. This is because those instruments often rely on many vague, locally specific, and sometimes dogmatic criteria. Criteria include learners’ needs,

\footnotetext{
*Acknowledgment: This article is funded by the Confucius Institute Headquarters (Hanban) Commissioned Project: Comparative Research on International Language and Culture Promotion Organizations (No.: 18CI03D).

Yu Dongxing, Dr., assistant professor, School of Open Learning and Education, Faculty of Education, East China Normal University (You can visit the author's personal ORCID ID at https://orcid.org/0000-0002-5976-1782).
} 
goals, learning styles, and proficiency levels; classroom contexts and processes; the potential of the materials for generating motivation, variety, and interest; and language teaching methods. Additionally, the judgments elicited by such criteria tend to be subjective and difficult to quantify, hence unreliable.

There are different types of material evaluation. Cunningsworth (1995) and Ellis (1997) argued that the most common form is probably the "pre-use" evaluation that is designed to examine the future or potential performance of a textbook. The other types of textbook evaluation are the "in-use" evaluation designed to examine material that is currently being used and the "post-use" (reflective) evaluation of a textbook that has been used in any respective institution. Despite the fact that textbooks are an important element in most of Chinese foreign learners (CFL) classes, there has been little investigation done in terms of the students' evaluation of the textbooks. The reason for this may lie in the fact that in the age of communicative teaching, experts who advise on the use of textbooks may seem out of step with current language teaching methodology, and teachers will choose textbooks simply by their personal preferences. Yet, regardless of how great an emphasis is placed on the use of authentic materials, teachers frequently do not have the time and the administrative support to collect and adapt all the necessary materials for their classes. Therefore, it is disappointing that researchers have not provided more guidance to enable teachers and administrators to make wiser decisions, especially the feedback from the students' perspective.

A strong association exists between the contents of textbooks and the learning of the students, which makes textbook evaluation from students' perspective a task of great importance to the future success of an educational program.

The role of published Chinese textbooks, however, is not only help teachers, but also those interested in studying Chinese, since they can consult and use them as tools for revising prior knowledge, and for getting an idea of their future acquisitions. The weaknesses of using a pre-conceived textbook, such as the poor relevance of content for students, lack or unbalanced variety of certain tasks, and the existence of non-stimulating, even uninteresting activities and content. Student needs and expectations as well as program expectations must be met appropriately. The careful scrutiny of the text intended for use is not enough. Learners of Chinese as a foreign language often do not have much chance to speak or use the target language because learning is limited to the classroom environment and they have little contact with Chinese or Chinese (native) speakers. As a result, it is essential that texts and materials provide learners with knowledge of the target language and culture as accurately and objectively as possible.

We believe that the analysis and evaluation of Chinese textbook by students gives us a clearer picture of their needs in order to promote real communication situations and the students' autonomy, even if a textbook presents in Hutchinson and Torres' (1994, p. 315) opinion the danger according to which the teacher can be relieved from the responsibility for the selection and development of materials suitable for students' needs, because we can assume that using a pre-existing textbook meets the criteria of appropriate teaching. This research aims to carry out a practical analysis method from the learner's demand in order to develop a textbook that suits the original purpose and provides a basis for the future educational environment, upon recognizing the importance of textbook development in the field of teaching Chinese as a foreign language.

\section{Research Methodology}

The starting point of the research was the evaluation grid of the English textbook used by Paul Dickinson (2010) and which was adapted taking into account the suggestions of Littlejohn (1998), who, in assessing a 
textbook identifies three levels of analysis, namely: form, content and evaluation. The grid was given to 64 students enrolled the Aarhus University of in Denmark in the academic year 2015-2016. The variables proposed to the students were: general appearance and attractiveness, topic contents, vocabulary and grammar, types of exercises and activities, practice, and assessment. Each variable considered five items, as shown in Table 1 below. The questionnaires in English were administered to the chosen students. For collecting data from the students, the researchers distributed the instrument during class time preceded by a brief explanation of the purpose and the nature of the study and if they had difficulty in the interpretation of any item, the researchers helped them to understand the item.

After the collection of the instrument, it was collected for data analysis. The means of the students in each single item were calculated to summarize the teachers' and students' views about the textbook. The evaluation form completed by the students is shown below as well as the answers provided by the respondents, both in number and percentage.

Table 1

Total Survey Data

\begin{tabular}{|c|c|c|c|c|c|c|c|c|c|c|}
\hline & 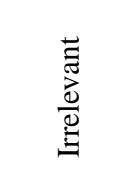 & & 客 & & 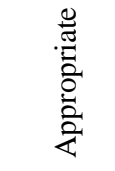 & & تृ & &  & \\
\hline General appearance & $\%$ & No. & $\%$ & No. & $\%$ & No. & $\%$ & No. & $\%$ & No. \\
\hline $\begin{array}{l}\text { 1. The font size and type used in the book are } \\
\text { appropriate for the learners. }\end{array}$ & $8.82 \%$ & 3 & $0.00 \%$ & & $32.35 \%$ & 11 & $23.53 \%$ & 8 & $35.29 \%$ & 12 \\
\hline $\begin{array}{l}\text { 2. The book has a complete and detailed table } \\
\text { of contents. }\end{array}$ & $2.94 \%$ & 1 & $2.94 \%$ & 1 & $35.29 \%$ & 12 & $41.18 \%$ & 14 & $17.65 \%$ & 6 \\
\hline 3. Every lesson is given an appropriate title. & $2.94 \%$ & 1 & $2.94 \%$ & 1 & $11.76 \%$ & 4 & $61.76 \%$ & 21 & $20.59 \%$ & 7 \\
\hline 4. The book has an appropriate glossary. & $0.00 \%$ & & $14.71 \%$ & 5 & $23.53 \%$ & 8 & $29.41 \%$ & 10 & $32.35 \%$ & 11 \\
\hline 5. The book has a complete bibliography. & $8.82 \%$ & 3 & $17.65 \%$ & 6 & $44.12 \%$ & 15 & $17.65 \%$ & 6 & $11.76 \%$ & 4 \\
\hline \multicolumn{11}{|l|}{ Topic contents } \\
\hline $\begin{array}{l}\text { 1. The topics of the book are varied and } \\
\text { engaging to appeal to foreign students with } \\
\text { different interests and personalities. }\end{array}$ & $0.00 \%$ & & $11.76 \%$ & 4 & $47.06 \%$ & 16 & $29.41 \%$ & 10 & $11.76 \%$ & 4 \\
\hline $\begin{array}{l}\text { 2. The subject matter is presented in a logical, } \\
\text { organized manner. }\end{array}$ & $0.00 \%$ & & $20.59 \%$ & 7 & $26.47 \%$ & 9 & $38.24 \%$ & 13 & $17.65 \%$ & 6 \\
\hline $\begin{array}{l}\text { 3. The reading selections reflect real } \\
\text { communicative situations. }\end{array}$ & $2.94 \%$ & 1 & $32.35 \%$ & 11 & $44.12 \%$ & 15 & $17.65 \%$ & 6 & $2.94 \%$ & 1 \\
\hline $\begin{array}{l}\text { 4. The content contains real-life issues that } \\
\text { challenge the reader to think critically about } \\
\text { his/her worldview. }\end{array}$ & $11.76 \%$ & 4 & $52.94 \%$ & 18 & $32.35 \%$ & 11 & $2.94 \%$ & 1 & $0.00 \%$ & \\
\hline $\begin{array}{l}\text { 5. The topics encourage students to express } \\
\text { their own views. }\end{array}$ & $0.00 \%$ & & $23.53 \%$ & 8 & $41.18 \%$ & 14 & $29.41 \%$ & 10 & $5.88 \%$ & 2 \\
\hline \multicolumn{11}{|l|}{ Vocabulary and grammar } \\
\hline $\begin{array}{l}\text { 1. The book covers the main grammar items } \\
\text { appropriate to students. }\end{array}$ & $0.00 \%$ & & $5.88 \%$ & 2 & $35.29 \%$ & 12 & $44.12 \%$ & 15 & $14.71 \%$ & 5 \\
\hline $\begin{array}{l}\text { 2. The grammar rules are presented in a logical } \\
\text { manner and in increasing order of difficulty. }\end{array}$ & $0.00 \%$ & & $5.88 \%$ & 2 & $50.00 \%$ & 17 & $35.29 \%$ & 12 & $8.82 \%$ & 3 \\
\hline $\begin{array}{l}\text { 3. The book includes adequate materials for } \\
\text { learning vocabulary. }\end{array}$ & $0.00 \%$ & & $8.82 \%$ & 3 & $55.88 \%$ & 19 & $35.29 \%$ & 12 & $0.00 \%$ & \\
\hline $\begin{array}{l}\text { 4. The new vocabulary words are presented in } \\
\text { a variety of ways. }\end{array}$ & $0.00 \%$ & & $11.76 \%$ & 4 & $52.94 \%$ & 18 & $26.47 \%$ & 9 & $8.82 \%$ & 3 \\
\hline $\begin{array}{l}\text { 5. The new vocabulary words are presented at } \\
\text { an appropriate rate so that the text is } \\
\text { understandable and so that students are able to }\end{array}$ & $0.00 \%$ & & $14.71 \%$ & 5 & $32.35 \%$ & 11 & $47.06 \%$ & 16 & $5.88 \%$ & 2 \\
\hline
\end{tabular}


(Table 1 to be continued) retain new vocabulary.

Types of exercises and activities

1. There are interactive and task-based activities that require students to use new vocabulary to communicate.

2. Instructions in the textbook tell students to read for comprehension.

3. The activities facilitate students' use of grammar rules by creating situations in which these rules are needed.

4. The text makes comprehension easier by addressing a single new concept.

5. The exercises promote the critical thinking of the text.

$\begin{array}{lllllllllll}0.00 \% & & 11.76 \% & 4 & 35.29 \% & 12 & 50.00 \% & 17 & 2.94 \% & 1 \\ 5.88 \% & 2 & 5.88 \% & 2 & 47.06 \% & 16 & 32.35 \% & 11 & 8.82 \% & 3 \\ 2.94 \% & 1 & 8.82 \% & 3 & 41.18 \% & 14 & 44.12 \% & 15 & 8.82 \% & 3 \\ 0.00 \% & & 8.82 \% & 3 & 47.06 \% & 16 & 23.53 \% & 8 & 20.59 \% & 7 \\ 14.71 \% & 5 & 26.47 \% & 9 & 47.06 \% & 16 & 11.76 \% & 4 & 0.00 \% & \end{array}$

Practice and assessment

1. The book provides a variety of meaningful and mechanical exercises and activities to $\quad 0.00 \%$

$\begin{array}{lllllllll}0.00 \% & 11.76 \% & 4 & 47.06 \% & 16 & 38.24 \% & 13 & 2.94 \% & 1\end{array}$

practice language items and skills.

2. The book provides communicative exercises and activities that help students carry out their communicative tasks in real life.

\begin{tabular}{|c|c|c|c|c|c|c|c|c|c|}
\hline 3. The tasks of the exercises are clear. & $0.00 \%$ & & $14.71 \%$ & 5 & $50.00 \%$ & 17 & $23.53 \%$ & 8 & $11.76 \%$ \\
\hline $\begin{array}{l}\text { 4. There are a reasonable and appropriate } \\
\text { number of exercises. }\end{array}$ & $0.00 \%$ & & $5.88 \%$ & 2 & $41.18 \%$ & 14 & $50.00 \%$ & 17 & $2.94 \%$ \\
\hline $\begin{array}{l}5 \text {. The tests are valid and contain correct } \\
\text { language. }\end{array}$ & $5.88 \%$ & 2 & $2.94 \%$ & 1 & $52.94 \%$ & 18 & $35.29 \%$ & 12 & $2.94 \%$ \\
\hline
\end{tabular}

\section{Data Interpretation}

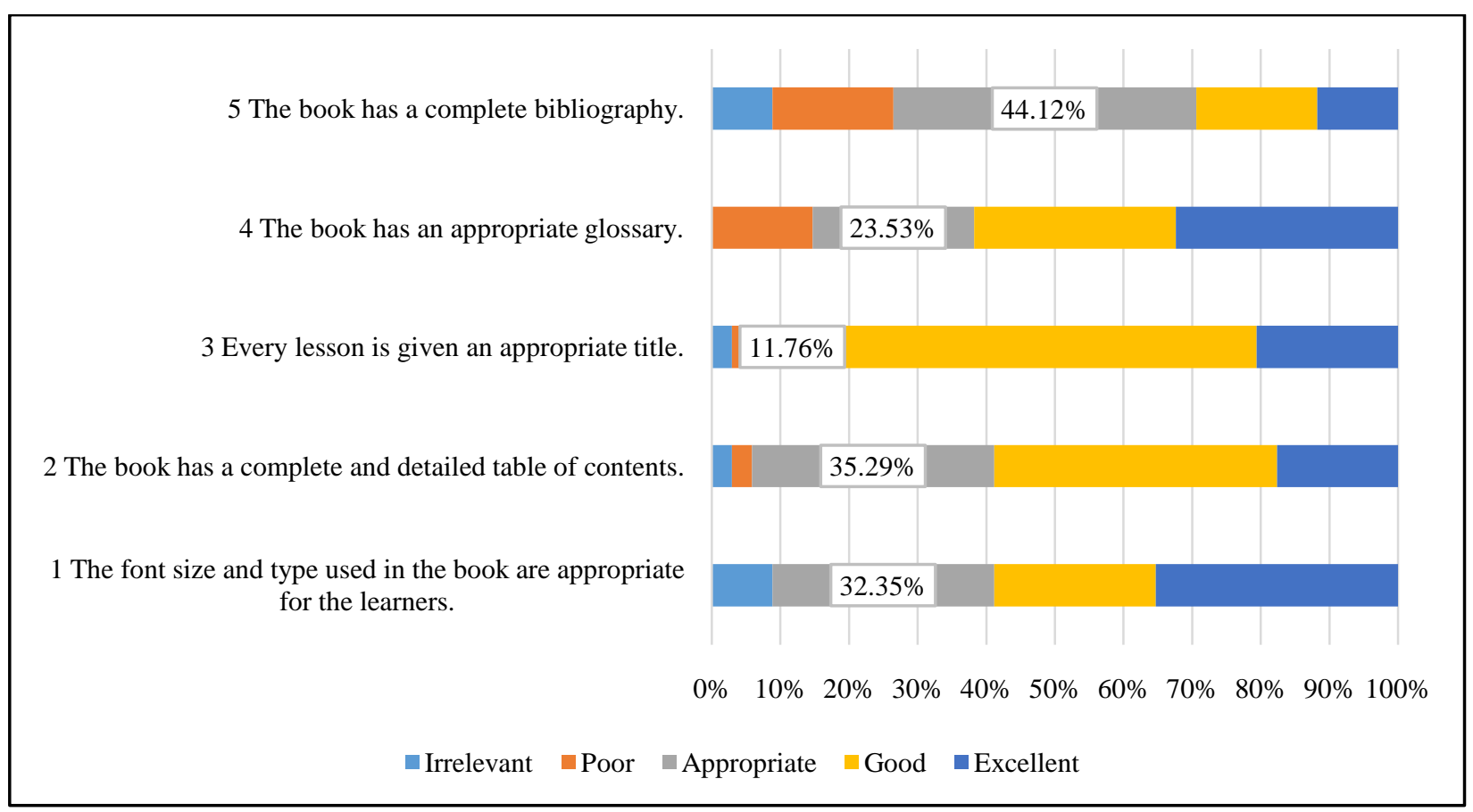

Figure 1. General appearance.

“General appearance” presents graphically the results on the first variable considered (see Figure 1). With regard to students' responses on the five descriptors which represent the first variable, it is noted that Items 3,1 , 
4, and 2 meet positive reviews, while Item 5 is considered as being appropriate.

As seen in "Topic contents", only Item 1 is appreciated by students as good, while no item is considered to be excellent (see Figure 2). Regarding Item 4 which has in view the appropriateness of content to real communication situations, students classify it as poor.

The purpose of the third variable was assessing whether the vocabulary and grammar are easy to understand and to learn (see Figure 3). After analyzing the responses, it appears that all items received favorable comments from students.



Figure 2. Topic contents.

5 The new vocabulary words are presented at an appropriate rate so that the text is understandable and so that students are able to retain new vocabulary.

4 The new vocabulary words are presented in a variety of ways.

3 The book includes adequate materials for learning vocabulary.

2 The grammar rules are presented in a logical manner and in increasing order of difficulty.

1 The book covers the main grammar items appropriate to students.

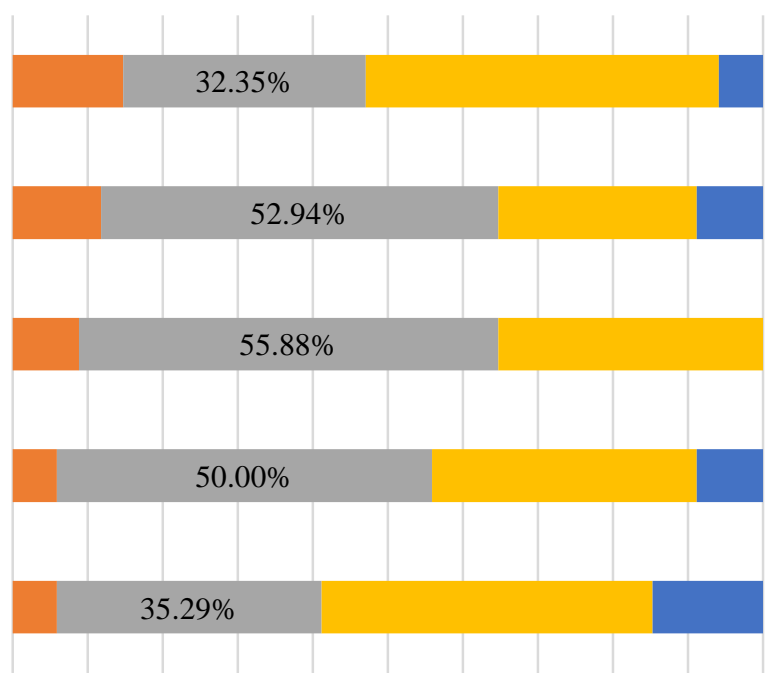

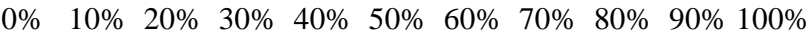

Irrelevant $\square$ Poor $\square$ Appropriate $\square$ Good $\square$ Excellent

Figure 3. Vocabulary and grammar. 
5 The exercises promote the critical thinking of the text.

4 The text makes comprehension easier by addressing a single new concept.

3 The activities facilitate students'use of grammar rules by creating situations in which these rules are needed.

2 Instructions in the textbook tell students to read for comprehension.

1There are interactive and task-based activities that require students to use new vocabulary to communicate.

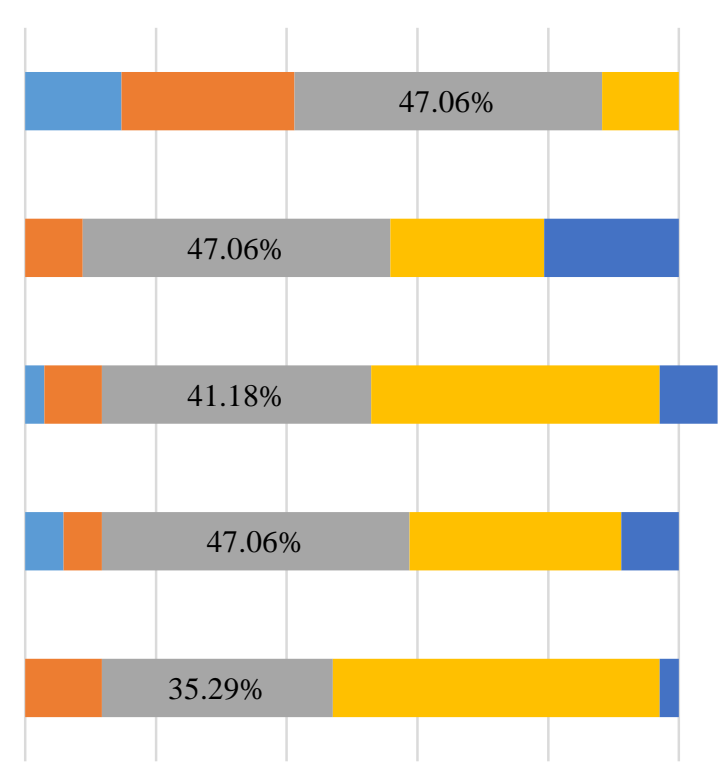

- Irrelevant $\square$ Poor $\square$ Appropriate $\square$ Good $\square$ Excellent

Figure 4. Type of exercises and activities.

5 The tests are valid and contain correct language.

4 There is a reasonable and appropriate number of exercises.

3 The tasks of the exercises are clear.

2 The book provides communicative exercises and activities that help students carry out their communicative tasks in real life.

1 The book provides a variety of meaningful and mechanical exercises and activities to practice language items and skills.
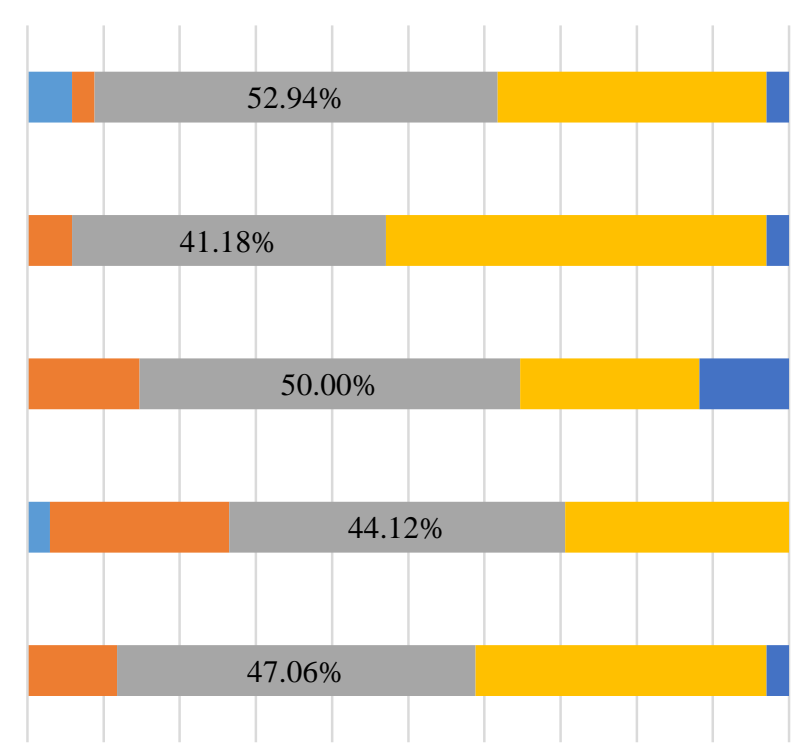

$\begin{array}{lllllllllll}0 \% & 10 \% & 20 \% & 30 \% & 40 \% & 50 \% & 60 \% & 70 \% & 80 \% & 90 \% & 100 \%\end{array}$

$\square$ Irrelevant $\square$ Poor $\square$ Appropriate $\square$ Good $\quad$ Excellent

Figure 5. Practice and assessment.

The fourth variable was assessing how the exercises and activities facilitate the understanding of the written texts (see Figure 4). After analyzing the responses, it appears that Items 1, 2, 3 and 4 received favorable comments from students. This is not valid for Item 5 , students observing the lack of interactive activities that stimulate critical thinking based on the texts. 
The last variable received appreciation from all five items, but Item 2 was classified as poor by $24 \%$ indicating a weak representation of exercises and communicative activities meant to help students to transpose messages into communicative contexts (see Figure 5).

It can be seen from our analysis students' ability to interpret objectively the form and content of the textbook, given that during the academic year they mainly used it for the acquisition and consolidation of grammar structures. However, the monotony of some activities and tasks was felt and sanctioned as such by their judgments. We can find the items rankings of "positive evaluation" and "negative evaluation" as above (see Figures 6 \& 7).

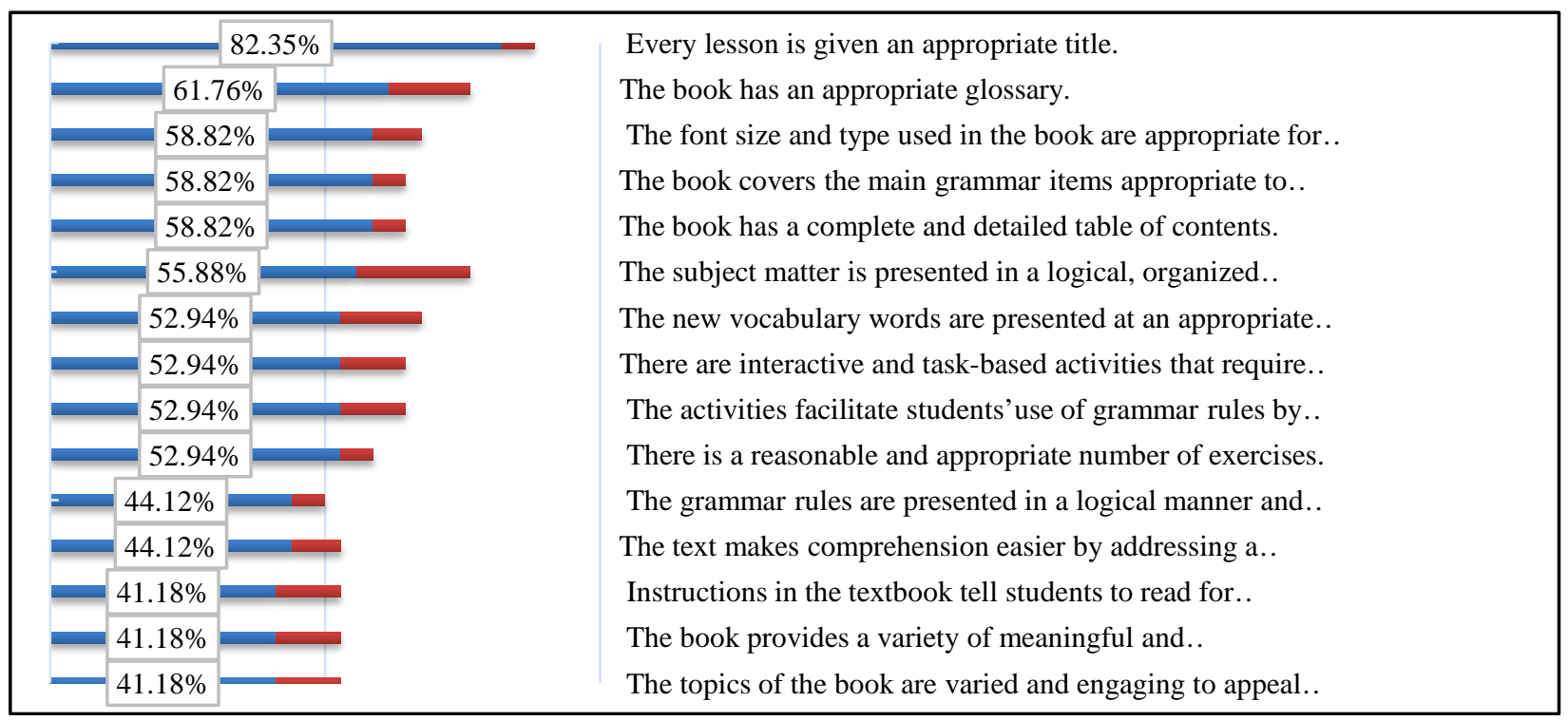

Figure 6. Rankings of "positive evaluation” and "negative evaluation” form.

The content contains real-life issues that challenge the reader to think critically about his/her worldview.

The exercises promote the critical thinking of the text.

The reading selections reflect real communicative situations.

The book provides communicative exercises and activities that help students carry out their communicative tasks in...

The book has a complete bibliography.

The topics encourage students to express their own views.

The tasks of the exercises are clear.

The new vocabulary words are presented in a variety of ways.

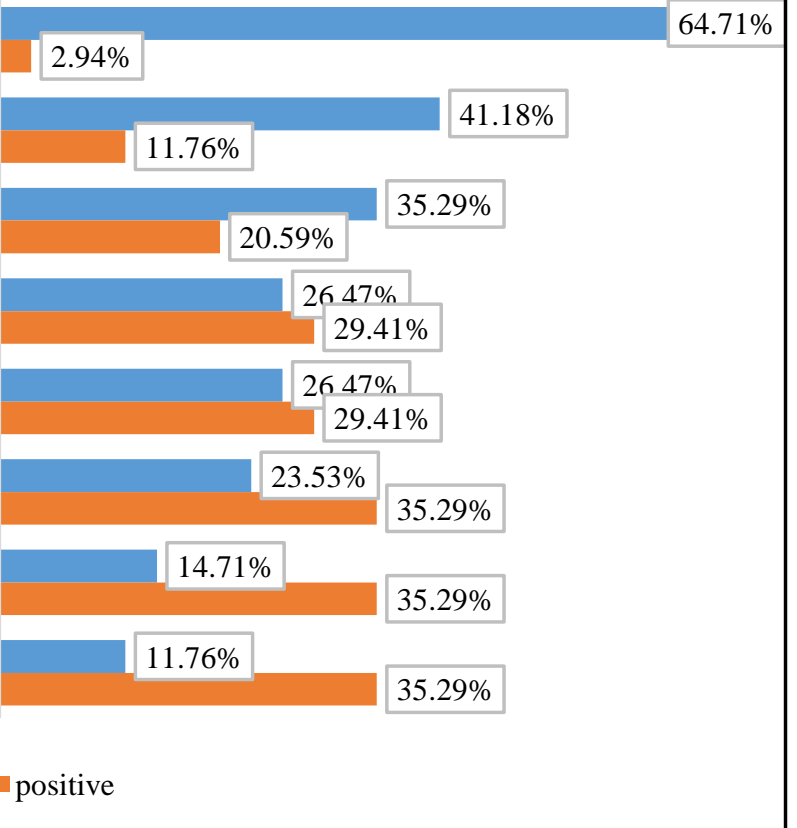

Figure 7. Rankings of "positive evaluation” and "negative evaluation” content. 


\section{Discussion and Conclusions}

The results of the research highlight a general good assessment of "Intergrated Chinese" primarily due to the targeted morphological and semantic aspects which are connected with the general layout, content of units, language structures, applications and evaluation, secondly because it is the prescribed textbook in Aarhus University. Students also underlined the coherent and systematic presentation of information. However, they noticed that the lack of diverse topics adapted to the current socio-cultural contexts, the lack of exercises that stimulate creativity and critical thinking or encourage the production and understanding of messages in communicative contexts, the difficulty of some activities that would involve an appropriate adjustment to different levels of understanding and lack of some tasks involving the production of written texts.

Textbooks are commodities, political objects, and cultural representations, and therefore, are the site and result of struggles and compromise in order to determine how and by whom they will be produced, how and by whom their contents will be selected, how and to whom they will be distributed, and how teachers and students will make use of them (Shannon, 2010). Chinese textbook's editing should be considered in a bigger picture including the new e-learning context and the new role the teacher should play in an interactive rather than one way teaching mode. From this research, it shows the textbooks cannot meet the students' demands about critical thinking and real life communication in an appropriate way even the students thought that they accomplished the textbook learning very well.

Second language learning is a complicated cognitive progress which has big difference in person. This means human beings especially those adult language learners can never be treated like a computer by inputting and outputting naturally. Since the 1970's, to make learners the center of language instruction has been a movement. To establish and apply a wide variety of relevant and contextually appropriate criteria for the evaluation of the textbooks that we use in Chinese as second language learning classrooms, we must make every effort to ensure "that careful selection is made, and that the materials selected closely reflect (the needs of the learners and) the aims, methods, and values of the teaching program” (Cunningsworth, 1995, p. 7).

It is difficult to define the role of the textbook in the language classroom perfectly and exactly. The students' needs cannot be meted by using only textbooks, from cover to cover, without any supplemental material. However, both teachers and students need a framework on which to build and textbooks definitely provide this. It is important that instructors strike a balance between being a slave to their texts and providing organized, objective-based instruction (Garinger, 2002). Using a textbook should like taking an adventure, the reader/learner can learn and explore in an interactive way instead of being forced to memorize those right rules and perform in fixed way.

How to present cultural content without stereotypes, while keep information relevant and interesting, often turn out to be problematic and will be challengeable in future. Evaluation is a dynamic process. Try to embrace the new technology and new findings from other disciplines. The correlation between critical thinking and second language acquisition is worth studying. Although critical thinking is a relatively new term that has been proposed in the 20th century, however, this activity is rooted in the thought of the ancient Greek philosophers, such as Socrates, Plato, and Aristotle. Since the beginning of the 20th century, following the development of related research on teaching and learning, critical thinking was highly emphasized (Gunn, Grigg, \& Pomahac, 2008). Critical thinking has a significant impact on student’s second language learning. Manshaee, Dastnaee, 
Seidi, and Davoodi's (2011) research indicates that it can be claimed with 99\% certainty that critical thinking is more in students interested in learning a second language than students uninterested in learning a second language.

\section{References}

Akbari, R. (2008). Post-method discourse and practice. TESOL Quarterly, 42(4), 641-652.

Allwright, R. L. (1981). What do we want teaching materials for? ELT Journal, 36(1), 5-17.

Ansary, H., \& Babaii, E. (2002). Universal characteristics of EFL/ESL textbooks: A step towards systematic textbook evaluation. The Internet TESOL Journal, 8(2).

Antón, M., \& DiCamilla, F. (1998). Socio-cognitive functions of L1 collaborative interactions in the L2 classroom. Canadian Modern Language Review, 54, 314-342.

Boriboon, P. (2008a). Cultural voices and representations in EFL materials design, pedagogy, and research (Unpublished Ph.D. thesis, University of Edinburgh).

Boriboon, P. (2008b). Learners' discursive voices in role play, dialogic means of meaning construction and their implications for innovative pedagogies. Innovation in Language Learning and Teaching, 2(2), 117-135.

Brown, J. (1995). The elements of language curriculum. Heinle \& Heinle Publishers.

Brown, G., \& Yule, G. (1983). Discourse analysis. Cambridge: Cambridge University Press.

Canagarajah, A. S. (1993a). American textbooks and Tamil students: Discerning ideological tensions in the ESL classroom. Language, Culture and Curriculum, 6(2), 143-156.

Canagarajah, A. S. (1993b). Critical ethnography of a Sri Lankan classroom: Ambiguities in student opposition to reproduction through TESOL. TESOL Quarterly, 27(4), 601-626.

Canagarajah, A. S. (Ed.). (2005). Reclaiming the local in language policy and practice. Mahwah, NJ: Erlbaum.

Chaidaroon, S. S. (2003). When shyness is not incompetence: A case of Thai communication competence. Intercultural Communication Studies, 12(4), 294-306.

Chandran, S. (2003). Where are the ELT textbooks? In W. A. Renandya (Ed.), Methodology and material design in language teaching: Current perceptions and practice and their implications (pp. 161-169). Singapore: SEAMEO Regional Language Centre. (RELC Anthology Series No. 44)

Cunningsworth, A. (1995). Choosing your course book. Oxford: McMillan Heinemann.

Dickinson, P. (2010). Evaluating and adapting materials for young learners. Retrieved April 7, 2020, from http://www.birmingham.ac.uk/Documents/collegeartslaw/cels/essays/younglearners/dickinsonYL.pdf

Edge, J., \& Wharton, S. (1998). Autonomy and development: Living in the materials world. In B. Tomlinson (Ed.), Materials development in language teaching (pp. 295-310). Cambridge: Cambridge University Press.

Ellis, R. (1997). The empirical evaluation of language teaching materials. English Language Teaching (ELT) Journal, 51(1), 1.

Garinger, D. (2002). Textbook selection for the ESL classroom. Retrieved April 8, 2020, from http://www.cal.org/resources/digest/0210garinger.html

Gunn, T. M., Grigg, L. M., \& Pomahac, G. A. (2008). Critical thinking in science education: Can bioethical issues and questioning strategies increase scientific understandings? The Journal of Educational Thought, 42(2), 165-183.

Graves, K. (2000). Designing language courses. Canada: Newbury House.

Hutchinson, T., \& Si Torres, E. (1994). The textbook as agent of change. ELT Journal, 48(4), 315-328.

Lee, W. (1997). The role of materials in classroom language use. In V. Berry., B. Adamson., and W. Littlewood (Eds.), Applying linguistics: Insights into language in education (pp. 69-82). Hong Kong: The University of Hong Kong.

Littlejohn, A. (1998). The analysis of language teaching materials: Inside the Trojan horse. In B. Tomlinson (Ed.), Materials development in language teaching (pp. 190-216). Cambridge: Cambridge University Press.

Manshaee, G., Dastnaee, T. M., Seidi, A., \& Davoodi, A. (2014). Comparison of critical thinking in students interested and uninterested in learning a second language. Theory and Practice in Language Studies, 4(4), 792-799.

O’Neil, R. (1982). Why use textbooks? ELT Journal, 36(2), 104-111.

Mares, C. (2003). Writing a course book. In B. Tomlinson (Ed.), Developing materials for language teaching (pp. 130-140). London: Continuum.

Moran, P. R. (2001). Teaching culture. London: Heinle \& Heinle Publishers.

Shannon, P. (2010). Textbook development and selection. International Encyclopedia of Education, 3, 397-402. 
Skierso, A. (1991). Textbook selection and evaluation. In C. M. Maria (Ed.), Teaching English as a second or foreign language (p. 441). Boston: Heinle \& Heinle Publishers.

Tomlinson, B. (Ed.). (2008). English language learning materials: A critical review. London: Continuum. Ur, P. (1996). A course in language teaching: Practice and theory. Cambridge: Cambridge University Press.

Wong, M. L. Y. (2011). Textbook evaluation: A framework for evaluating the fitness of The Hong Kong New Secondary School (NSS) Curriculum. Retrieved October 28, 2016, from http://asian-efl-journal.com/Thesis/Thesis-Wong.pdf 